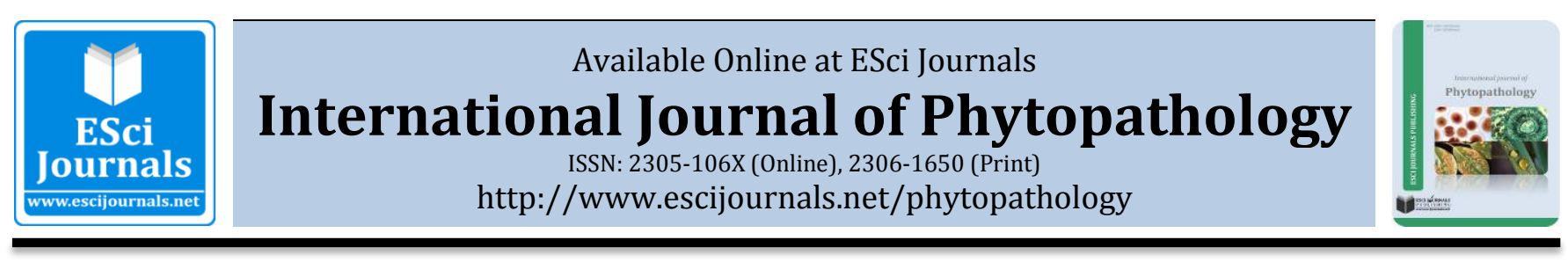

\title{
EFFECTS OF GLOMUS FASCICULATUM AND TRICHODERMA ASPERELLOIDES IN ROOTS OF GROUNDNUT (CV. WESTERN-51) AGAINST PATHOGEN SCLEROTIUM ROLFSII
}

\author{
Khirood Doley*, Mayura Dudhane, Mahesh Borde, Paramjit K. Jite \\ a Department of Botany, Mycology Lab, University of Pune, Maharashtra, Pune-411007, India.
}

\begin{abstract}
A B S T R A C T
Sclerotium rolfsii (Sacc.) is the causal agent of stem-rot of groundnut plants which is an important damaging soilborne root pathogen worldwide. Arbuscular mycorrhizal (AM) fungi (Glomus fasciculatum) and Trichoderma asperelloides have shown potential bio-control agent properties against several soil-borne plant pathogens. Interactions between $G$. fasciculatum, T. asperelloides and soil-borne pathogen $S$. rolfsii were investigated in this present pot culture experiment. The inoculation of $G$. fasciculatum and T. asperelloides reduced the severity of disease but their combinations were most effective in reducing harmful effects of $S$. rolfsii. The arbuscule percentage of AM fungi was affected by presence of T. asperelloides but chlorophyll content got increased by AM fungi or T. asperelloides treatments during $S$. rolfsii attack. The defense related physiological, biochemical and anti-oxidant activities observed in roots of groundnut plant significantly increased by single inoculation of AM fungi or Trichoderma. But, the combined inoculations of AM fungi and Trichoderma species showed the highest defense related activities. Moreover, single application of either AM fungi or Trichoderma species showed potential for the biocontrol of soil-borne plant pathogen but their combined application attributed most substantial inhibition in development of pathogen.
\end{abstract}

Keywords: AM fungi, antioxidant enzyme, biochemical, bio-control, chlorophyll, defense, disease severity, soilborne.

\section{INTRODUCTION}

Sclerotium rolfsii (Sacc.) is an economically significant soil-borne pathogen which causes diseases in about 500 species of plants. The fungus may survive in soil as sclerotia for 3-4 years but deep burying affects its viability Mehan et al. (1994). It has got distribution in tropics, subtropics and warm regions of the world. In India the climate is favorable for $S$. rolfsii in the states of Maharashtra, Gujrat, Andhra Pradesh and Tamil Nadu. India is the second largest producer of groundnut in the world with an annual production of 5.64 million tons in terms of cultivated groundnut (Arachis hypogaea L.) and it is considered to be an important oilseed crop of India (Madan Mohan and Nigam, 2013). However, the groundnut plant suffers from wide variety of pathogen attack which is being considered as major constraint in

\footnotetext{
* Corresponding Author:

Email: khirood_doleys@yahoo.com

(C) 2014 ESci Journals Publishing. All rights reserved.
}

its production. Among them S. rolfsii is one of the causal agent of stem-rot in groundnut plants. As the fungus is soil borne, it has potential to effect yield of groundnut pod (Melouk and Backman, 1995) which is why it is becoming inevitable to inhibit development of pathogens in groundnut plants. S. rolfsii often becomes difficult to control chemically hence, planting of resistant varieties seems to be an option. But, employing of microbial organisms for biological control can be a beneficial option because it will lessen the use of harmful chemicals. Besides, lesser use of chemicals would safeguard our environment in sustainable agriculture for our future generations. Among these microbial organisms, arbuscular mycorrhizal fungi (AMF) of phylum Glomeromycota have the potential for sustainable soil-plant systems (Smith and Read, 2008). In rhizosphere, the AM fungi help in uptake of nutrient and plays role in plant growth promotion with synergistic interaction with other micro-organisms 
(Bagyaraj and Verma, 1995). The AM fungi are also known for their ability to control soil-borne pathogen (Ziedan et al., 2011). That is why, the role of AM association in plant growth and their influence in biological control of soil or root-borne pathogens is of immense importance in the agricultural system. The AM fungi inhibit pathogen by mechanism of competition in root zones for its access, improved nutrition and/or collaboration of several mechanisms of resistance at the same time (Singh and Mukherji, 2006; Whipps, 2004). Likewise mycorrhiza, another symbiotic fungus with high taxonomic diversity popularly known for a long time as Trichoderma (teleomorph Hypocrea) is gaining importance which also establishes itself on groundnut plants (Kokalis-Burelle et al., 1997; Hermosa et al., 2010; Jaklitsch et al., 2013). Trichoderma associations have been shown to inhibit pathogen development by mechanism of mycoparasitism (Reithner et al., 2011). Moreover, the ubiquitous distribution Trichoderma species in soil and properties of growth promoter in plant makes it good candidature along with AM fungi for low input bio-fertilizer to keep our environment clean. That may be the reason why Trichoderma based formulations is making its way into commercial world of bio-fungicides (Topolovec-Pintaric et al., 2013). Hence, the interactive activities of indigenous microbes that are present in rhizosphere have to be utilized for the modern day agricultural practices.

Thus, in the present pot investigation, the interaction between G. fasciculatum and T. asperelloides (formerly known as T. viride, Mukherjee et al., 2013) were evaluated for their individual and combined effects on local groundnut cultivar when infected with pathogen $S$. rolfsii.

\section{MATERIAL AND METHODS}

For a pot culture investigation seeds of local groundnut cultivar Western-51 were planted in sterilized soil. The biological antagonist Glomus fasciculatum (Gerd.) was isolated from the soil as per Gerdemann and Nicholson (1963) and their identification was carried out as per synoptic keys suggested by Trappe (1982). The $G$. fasciculatum was mass multiplied for three months with host Sorghum vulgare grown on $30 \mathrm{~cm}^{3}$ earthen pots containing 10-15 kg of sterilized soil and sand in a proportion of 1:1 which served as AM inoculum (20 g), containing spores along with colonized root pieces. Before sowing of groundnut AM inoculum were placed at about 3-5 cm below seeds. Another talc based antagonist
T. asperelloides was obtained from the Microbiology Department, Agriculture College, Pune, India and it was applied at the rate of $4 \mathrm{~g}$ per $\mathrm{kg}$ of groundnut seeds before AM inoculation and sowing. For pathogen inoculum, S. rolfsii was isolated from the fields of Pune district which was purified and identified through the Division of Agharkar Research Institute, Maharashtra, Pune, India. The mass multiplication of $S$. rolfsii was done by taking sterilized sorghum seeds in conical flasks by inoculating with $5 \mathrm{~mm}$ mycelial disc taken from the active periphery of a 7-day-old pure culture of $S$. rolfsii in each bottle which were incubated for 3 weeks at temperature $28^{\circ} \mathrm{C}$. From this grain culture pathogen inoculum were applied below each groundnut plants at the rate of $5 \mathrm{~g}$ after 15 days of growth. The plants were watered at regular periods without any kind of chemical application. After 30, 60 and 90 days of growth plants were harvested for arbuscule percentage, physiological and biochemical parameters from AM/Trichoderma treated healthy/infected groundnut plants.

Enzyme extraction and activity assay: Acid and alkaline phosphatase was estimated as per Lowry et al. (1954) where substrate solution of acid and alkaline phosphatase consisted of $1.49 \mathrm{~g}$ EDTA, $0.84 \mathrm{~g}$ citric acid, $0.03 \mathrm{~g} \mathrm{p}$-nitro phenyl phosphate dissolved in $100 \mathrm{ml}$ water and $375 \mathrm{mg}$ glycine, $10 \mathrm{mg}$ magnesium chloride, $165 \mathrm{mg}$ p-nitro phenyl phosphates dissolved in $42 \mathrm{ml}$ of $0.1 \mathrm{~N}$ sodium hydroxide diluted $100 \mathrm{ml}$ water respectively. For enzymes extract of acid and alkaline phosphatase sample root $(1 \mathrm{~g})$ was homogenized in 10 $\mathrm{ml} 50 \mathrm{mM}$ citrate buffer and $50 \mathrm{mM}$ glycine $\mathrm{NaOH}$ buffer respectively in a pre-chilled mortar and pestle which was filtered through cheese cloth and centrifuged. Supernatant was used as enzyme source. In procedure 3 $\mathrm{ml}$ of substrate solution was incubated at $37^{\circ} \mathrm{C}$. $0.5 \mathrm{ml}$ enzyme extract was added with immediate removal and mixed with $9.5 \mathrm{ml}$ sodium hydroxide $0.085 \mathrm{~N}$ (Blank). Remaining solution (substrate+enzyme) was incubated for 15 minutes at $37^{\circ} \mathrm{C} .0 .5 \mathrm{ml}$ of this was taken and mixed with $9.5 \mathrm{ml}$ sodium hydroxide solution. Absorbance of blank and incubated tubes was read at $405 \mathrm{~nm}$ by using UV-visible spectrophotometer (Shimadzv-1601). 0.2 to $1.0 \mathrm{ml}(4-20 \mathrm{mM})$ of the standard was taken and diluted to $10.0 \mathrm{ml}$ with sodium hydroxide solution. The standard curve was plotted and amount of acid and the amount of acid and alkaline phosphatase was expressed as moles of p-nitrophenol released $\mathrm{g}^{-1}$ of fresh weight in roots. 
Total protein was assayed according to Lowry et al. (1951) where $1 \mathrm{~g}$ of root samples was homogenized in 10 $\mathrm{ml}$ of phosphate buffer and centrifuged at $15000 \mathrm{rpm}$ $\left(4^{\circ} \mathrm{C}\right)$. The supernatant was mixed with $20 \mathrm{ml}$ acetone and $14 \mu \mathrm{l} \beta$-mercaptoethanol for precipitation of proteins. The sample tubes were then again centrifuged for $20 \mathrm{~min}$. The obtained pellets were dissolved in sodium hydroxide solution and used as the source of proteins. Blank was set with $1 \mathrm{ml}$ distilled water. A series of working standard solution was taken with distilled water. $5 \mathrm{ml}$ of alkaline copper solution was added to each test tube and mixed thoroughly. After keeping test tubes at RT for $10 \mathrm{~min}, 0.5$ $\mathrm{ml}$ of Folin- Ciocalteau was added, mixed well and the tubes were kept in dark for $20 \mathrm{~min}$. The absorbance of the blue colour developed due to the addition of FolinCiocalteau reagent was read at $660 \mathrm{~nm}$. A standard graph was obtained and the optical density of extract were measured and plotted on the standard curve. The amount of protein was expressed as protein in $\mu^{-1} \mathrm{~g}^{-1}$ fresh weight. Polyphenol oxidase (PPO) was measured as per Mahadevan and Shridhars, 1982). Root samples were crushed and centrifuged supernatant was used as enzyme source. $1 \mathrm{ml}$ of $0.1 \mathrm{M}$ phosphate buffer, $1 \mathrm{ml}$ of catechol and $0.5 \mathrm{ml}$ of enzyme extract was added to it and initial optical density was measured at $495 \mathrm{~nm}$ and then the absorbance was measured at the interval of every 30 seconds for 3 minutes on spectrophotometer. The polyphenol oxidase activity was expressed as min $^{-1}$ $\mathrm{g}^{-1}$ fresh weight.

Total phenols were determined according to Malick and Singh, (1980). Root samples were homogenized, centrifuged and supernatant was condensed on hot water bath to $1.0 \mathrm{ml}$ with final volume made up to $50 \mathrm{ml}$ with distilled water. From this, $0.5 \mathrm{ml}$ of sample extract was taken and adjusted to $3.0 \mathrm{ml}$ with distilled water. After preparing a series of working standard solution, $0.5 \mathrm{ml}$ of Folin reagent was added. After 2 minutes, $2 \mathrm{ml}$ of $20 \% \mathrm{Na}_{2} \mathrm{CO}_{3}$ was added and then contents were boiled for a minute and cooled. Optical density was recorded at $650 \mathrm{~nm}$ using spectrophotometer. A standard graph was prepared on which the concentration of the total phenols in the sample was obtained. The amount of phenol was expressed as mg phenols $\mathrm{g}^{-1}$ fresh weight.

Peroxidase activity was determined according to Putter (1974). Reaction mixture was prepared with $3 \mathrm{ml}$ of buffer solution ( $\mathrm{pH}$ 7), $0.05 \mathrm{ml}$ guaiacol solution, $0.1 \mathrm{ml}$ enzyme extract and $0.03 \mathrm{ml}$ hydrogen peroxide solution.
Initial absorbance was read at $436 \mathrm{~nm}$ and then optical density was noted at an interval of 30 seconds on spectrophotometer. The enzyme activity was expressed as $\mathrm{min}^{-1} \mathrm{mg}^{-1}$ protein.

Total chlorophyll was measured by methodology described by Arnon (1949). Leaf sample was grounded with $80 \%$ acetone and centrifuged twice until the residue became colourless. Finally, the supernatant was transferred to volumetric flask. Final volume was made to $100 \mathrm{ml}$ with $80 \%$ acetone. The absorbance of the solution was read at 663 and $645 \mathrm{~nm}$ against the solvent blank (80\% acetone) using spectrophotometer. Total chlorophyll was expressed as mg chlorophyll per $\mathrm{g}$ tissue.

Disease severity was calculated using rating scale of 1-5 as described by Shokes et al. (1996) as follows: $1=$ Healthy, $2=$ Lesions on stem only, $3=25 \%$ of plant symptomic to wilt, dead or dying, $4=26-50 \%$ of plant symptomic, $5=>50 \%$ of plant symptomic. Arbuscule percentage were determined as per Trouvelot et al., 1986.

This experiment consisted of eight treatments namely, $\mathrm{C}=$ control uninoculated, $S r=$ pathogen $S . \quad$ rolfsii inoculated, $T a=T$. asperelloides inoculated, $T a+S r=T$. asperelloides and $S$. rolfsii inoculated, $G f=G$. fasciculatum inoculated, $G f+S r=G$. fasciculatum and $S$. rolfsii inoculated, $G f+T a=G$. fasciculatum and $T$. asperelloides inoculated, $G f+S r+T a=G$. fasciculatum, $S$. rolfsii and $T$. asperelloides inoculated. Data were analyzed using one way analysis of variance (ANOVA) followed by Duncan's Multiple Range Test (DMRT). Values were mean of \pm SE $(n=3)$. Duncan's multiple range test was applied as post hoc test at $p=0.05$. All the calculations were made by using a Statistical Package for Social Sciences (SPSS) for windows version 9.0 and Microsoft Excel 2007 to analyze the data.

\section{RESULTS}

In results (see Figure 1 and 2), the acid and alkaline phosphatase activities got enhanced in treatments such as $G f, G f+S r, G f+T a$ and $G f+S r+T a$ as compared to their respective control ones after 30,60 and 90 days of sowing but highest phosphatase activities were observed when both AM fungi and Trichoderma were inoculated in presence of pathogen $(G f+S r+T a)$ $(5.692 \pm 0.167 \mathrm{pnp} / \mathrm{g}$ for acid and $6.900 \pm 0.181 \mathrm{pnp} / \mathrm{g}$ for alkaline phosphatase) after 90 days of sowing. The acid and alkaline phosphatase activities were lowest due to the presence of pathogen $(S r)$ when no inoculations of AM fungi or Trichoderma were made $(2.724 \pm 0.184$ 
pnp/g for acid and $2.397 \pm 0.167 \mathrm{pnp} / \mathrm{g}$ for alkaline phosphatase) after 90 days of sowing.

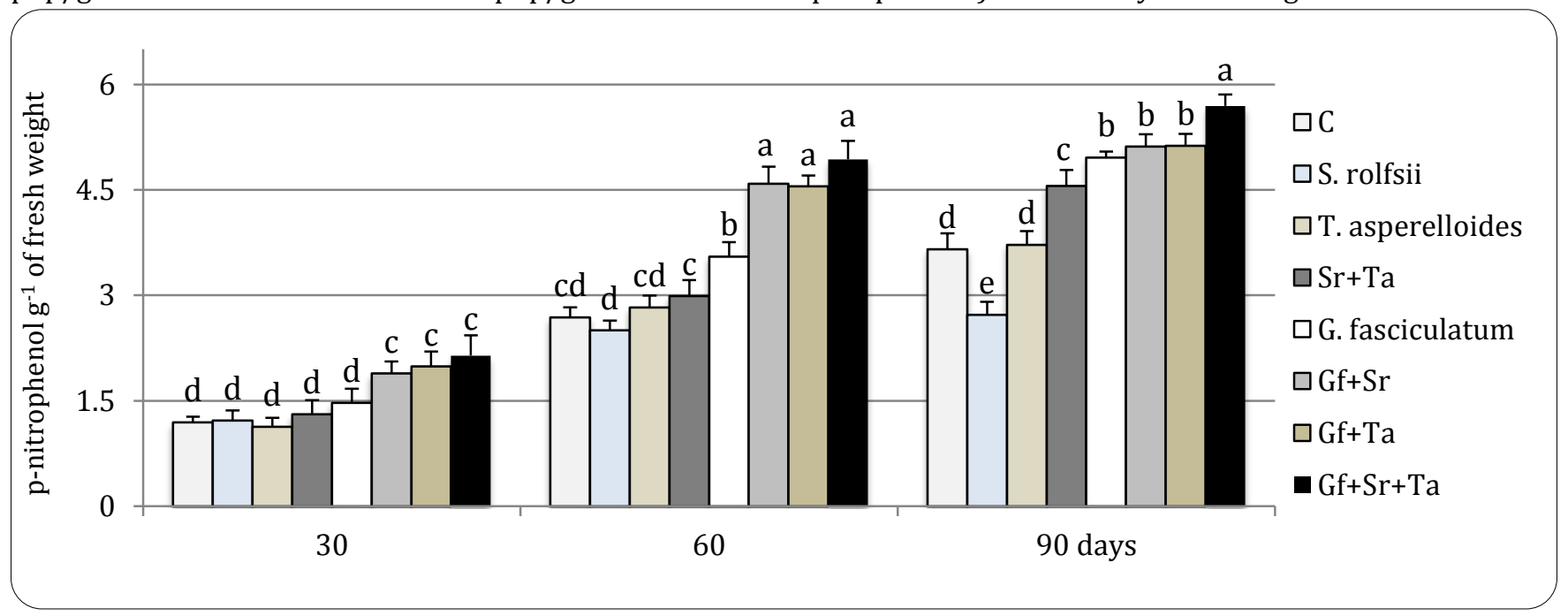

Figure 1. Acid phosphatase activity in roots of groundnut plants (W-51) inoculated with G. fasciculatum (Gf) and T. asperelloides (Ta) alone or 3in combinations infected with S. rolfsii (Sr) and at different period of growth.

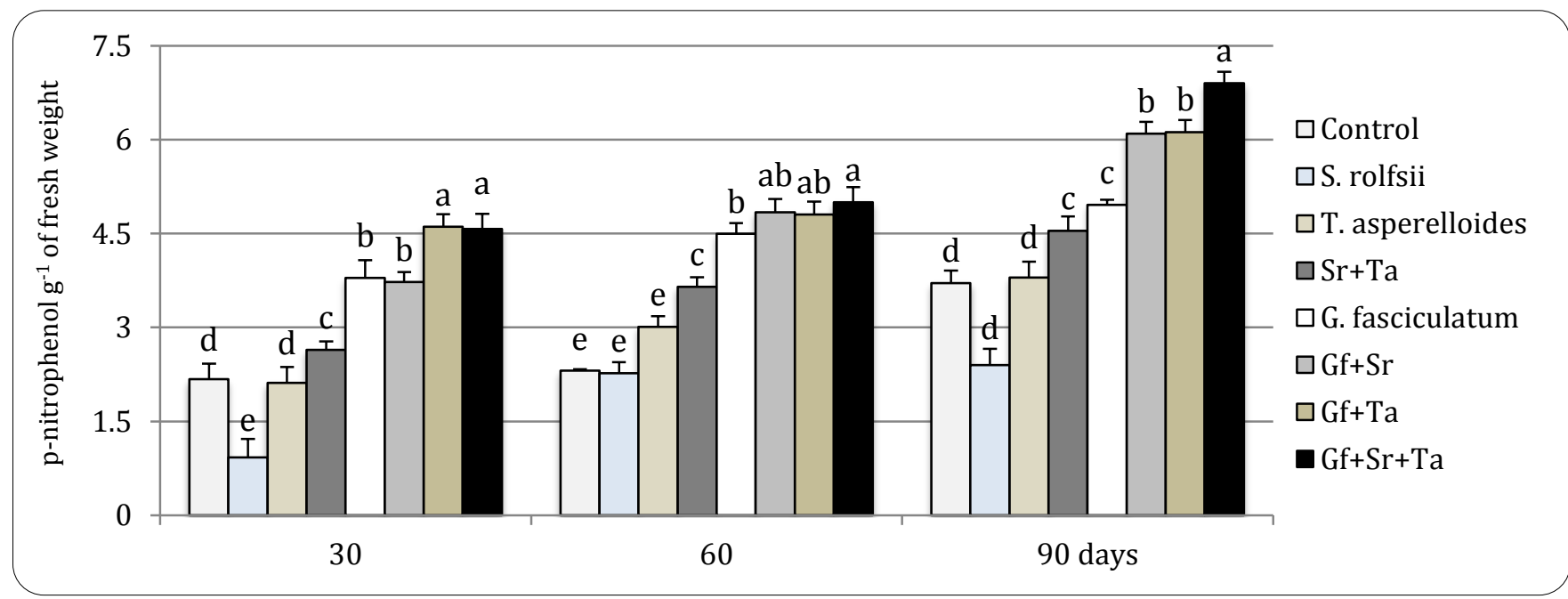

Figure. 2. Alkaline phosphatase activity in roots of groundnut plants (W-51) inoculated with G. fasciculatum (Gf) and T. asperelloides (Ta) alone or in combinations infected with S. rolfsii (Sr) and at different period of growth.

The protein activity was observed to be increased $(0.111 \pm 0.011 \mathrm{mg} / \mathrm{g})$ after 60 days in pathogen inoculated groundnut $(\mathrm{Sr})$ than only Trichoderma inoculated healthy plants $(T a)(0.110 \pm 0.009 \mathrm{mg} / \mathrm{g})$. Protein activities were higher in diseased AM fungi $(G f+S r)(0.224 \pm 0.009 \mathrm{mg} / \mathrm{g})$ and Trichoderma inoculations $(\mathrm{Sr}+\mathrm{Ta})(0.175 \pm 0.012 \mathrm{mg} / \mathrm{g})$ after 90 days of sowing. Especially when compared to healthy combined application of AM fungi/Trichoderma after 90 days of sowing $(G f+T a)(0.212 \pm 0.006 \mathrm{mg} / \mathrm{g})$. However, the highest activities were noted when combined application of AM fungi and Trichoderma were made in diseased groundnut plants $(G f+S r+T a)(0.236 \pm 0.013 \mathrm{mg} / \mathrm{g})$ after 90 days of sowing (Figure 3).
The PPO activity as illustrated in Figure 4 increased due to pathogen inoculation $(S r)\left(0.714 \pm 0.098 \mathrm{~min}^{-1} \mathrm{~g}^{-1}\right)$ than healthy Trichoderma inoculation $(\mathrm{Ta})\left(0.622 \pm 0.079 \mathrm{~min}^{-1} \mathrm{~g}\right.$ 1) after 30, 60 or 90 days of sowing. But, the PPO activities were enhanced in diseased Trichoderma $(\mathrm{Sr}+\mathrm{Ta})$ $\left(0.867 \pm 0.146 \mathrm{~min}^{-1} \mathrm{~g}^{-1}\right)$ or AM fungi treatments $(G f+S r)$ $\left(1.092 \pm 0.080 \mathrm{~min}^{-1} \mathrm{~g}^{-1}\right)$ as compared to single or combined application of healthy AM fungi $(G f)\left(0.833 \pm 0.101 \mathrm{~min}^{-1} \mathrm{~g}^{-1}\right)$ or Trichoderma $(G f+T a)\left(0.967 \pm 0.063 \mathrm{~min}^{-1} \mathrm{~g}^{-1}\right)$ treatments after 90 days of sowing. However, the highest PPO activity was observed in the combined application of AM fungi and Trichoderma in presence of $S$. rolfsii in groundnut plants $(G f+S r+T a)\left(1.167 \pm 0.151 \mathrm{~min}^{-1} \mathrm{~g}^{-1}\right)$ after 90 days of sowing. 


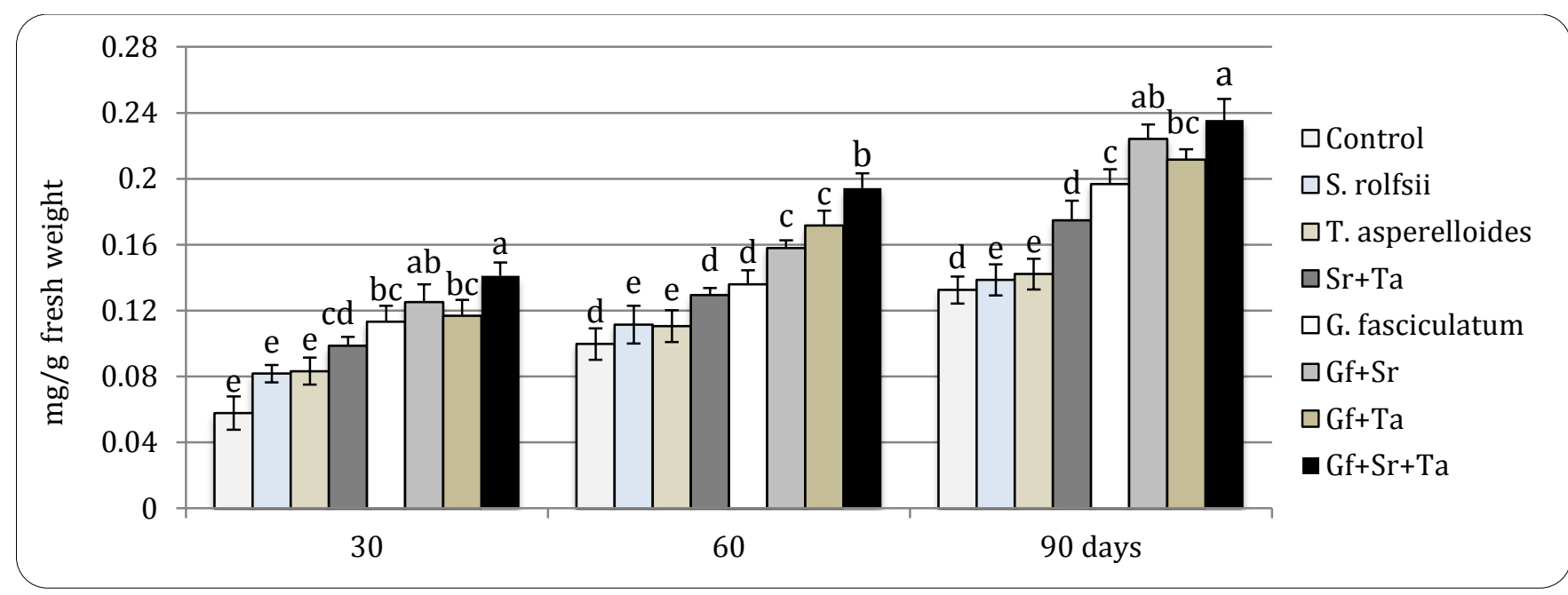

Figure 3. Protein activity in roots of groundnut plants (W-51) inoculated with G. fasciculatum (Gf) and T. asperelloides (Ta) alone or in combinations infected with $S$. rolfsii $(\mathrm{Sr})$ and at different period of growth.

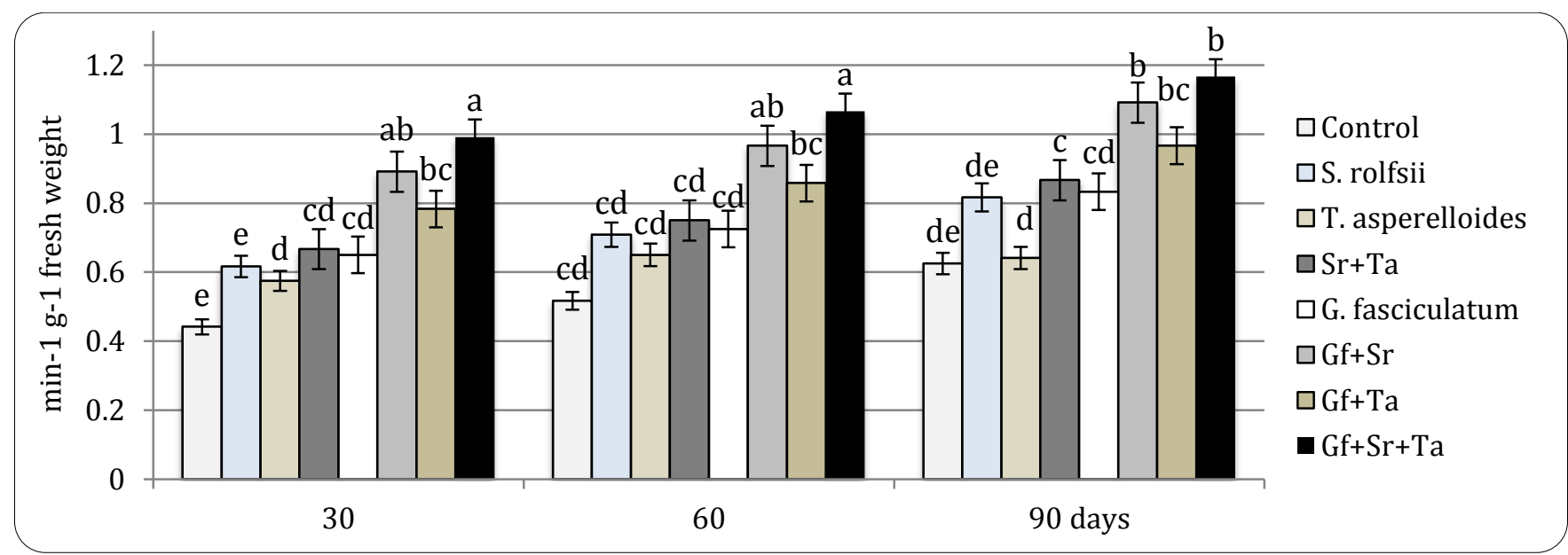

Figure 4. Polyphenol oxidase (PPO) activity in roots of groundnut plants (W-51) inoculated with G. fasciculatum (Gf) and T. asperelloides (Ta) alone or in combinations infected with S. rolfsii $(\mathrm{Sr})$ and at different period of growth.

The total phenol activity observed in groundnut roots showed increase in their content in control pathogen treatment $(S r) \quad(0.216 \pm 0.011 \mathrm{mg} / \mathrm{g})$ than healthy Trichoderma treatment $(\mathrm{Ta})(0.182 \pm 0.014 \mathrm{mg} / \mathrm{g})$ after 60 days of sowing. The higher content of phenols was observed in healthy AM fungi (Gf) $(0.299 \pm 0.014 \mathrm{mg} / \mathrm{g})$ or in diseased AM fungi treatments $(G f+S r)(0.324 \pm 0.019$ $\mathrm{mg} / \mathrm{g}$ ) but total phenols were higher in healthy combined treatment of AM fungi and Trichoderma $(G f+T a)(0.330 \pm 0.014 \mathrm{mg} / \mathrm{g})$. However, the phenol content was observed to highest in combined application of AM fungi and Trichoderma in presence of $S$. rolfsii $(G f+S r+T a)(0.534 \pm 0.028 \mathrm{mg} / \mathrm{g})$ after 90 days of sowing (Figure 5).

The activity of peroxidase enzyme was observed to be higher in diseased groundnut plants $(S r, S r+T a, G f+S r$,
$G f+S r+T a$ ) with their respective healthy ones (C, Ta, Gf, $G f+T a$ ) as illustrated (Figure 6). The higher peroxidase enzyme activity in healthy groundnut plants was observed in combined application of AM fungi and Trichoderma treatments $(G f+T a)\left(0.0096 \pm 0.0016 \mathrm{~min}^{-1}\right.$ $\mathrm{mg}^{-1}$ protein) followed by single treatment of AM fungi (Gf) $\left(0.0069 \pm 0.0010 \mathrm{~min}^{-1} \mathrm{mg}^{-1}\right.$ protein), Trichoderma (Ta) $\left(0.0048 \pm 0.0008 \mathrm{~min}^{-1} \mathrm{mg}^{-1}\right.$ protein) or control ones $\left(0.0036 \pm 0.0008 \mathrm{~min}^{-1} \mathrm{mg}^{-1}\right.$ protein). However, the highest peroxidase activity was observed in combined application of AM fungi and Trichoderma in diseased groundnut plants $(G f+S r+T a)(0.0155 \pm 0.0008$ $\mathrm{min}^{-1} \mathrm{mg}^{-1}$ protein) followed by single application of AM fungi $(G f+S r)\left(0.0119 \pm 0.0010 \mathrm{~min}^{-1} \mathrm{mg}^{-1}\right.$ protein $)$ or Trichoderma $(\mathrm{Sr}+\mathrm{Ta})\left(0.0107 \pm 0.0005 \mathrm{~min}^{-1} \mathrm{mg}^{-1}\right.$ protein) (Figure 6). 


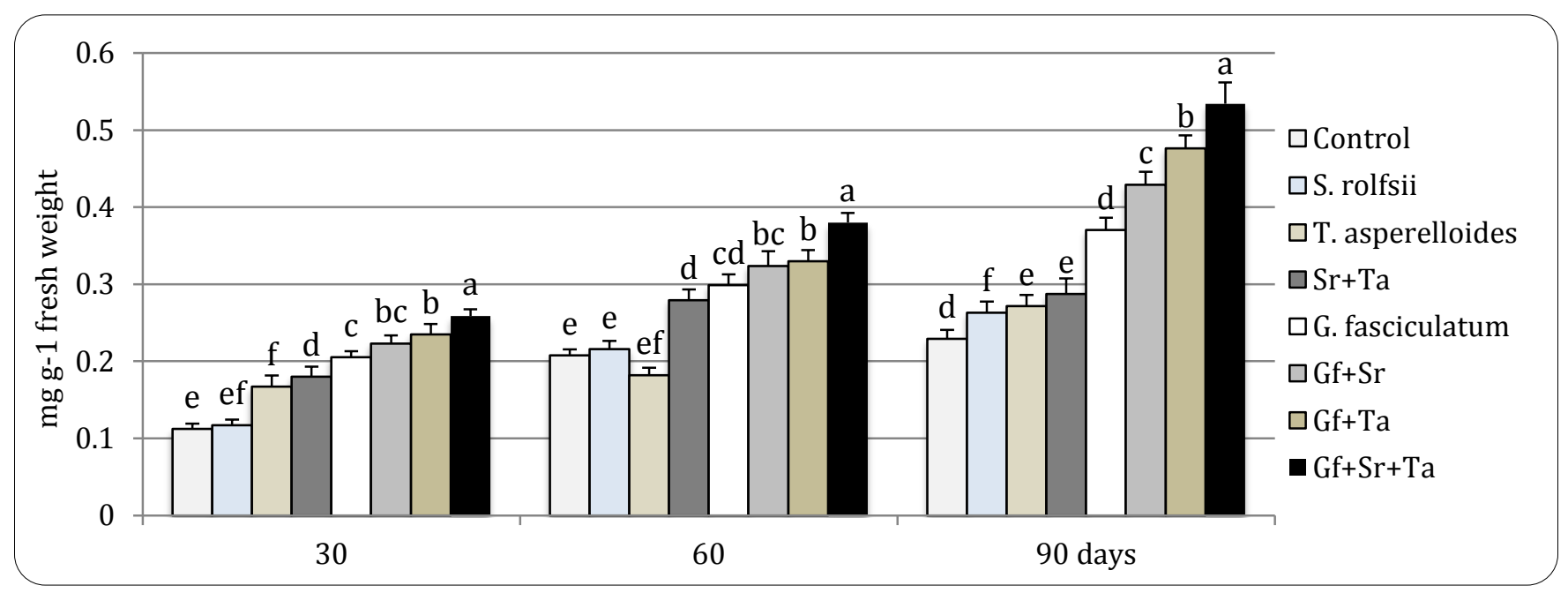

Figure 5. Total phenol activity in roots of groundnut plants (W-51) inoculated with G. fasciculatum (Gf) and $T$. asperelloides (Ta) alone or in combinations infected with $S$. rolfsii (Sr) and at different period of growth.

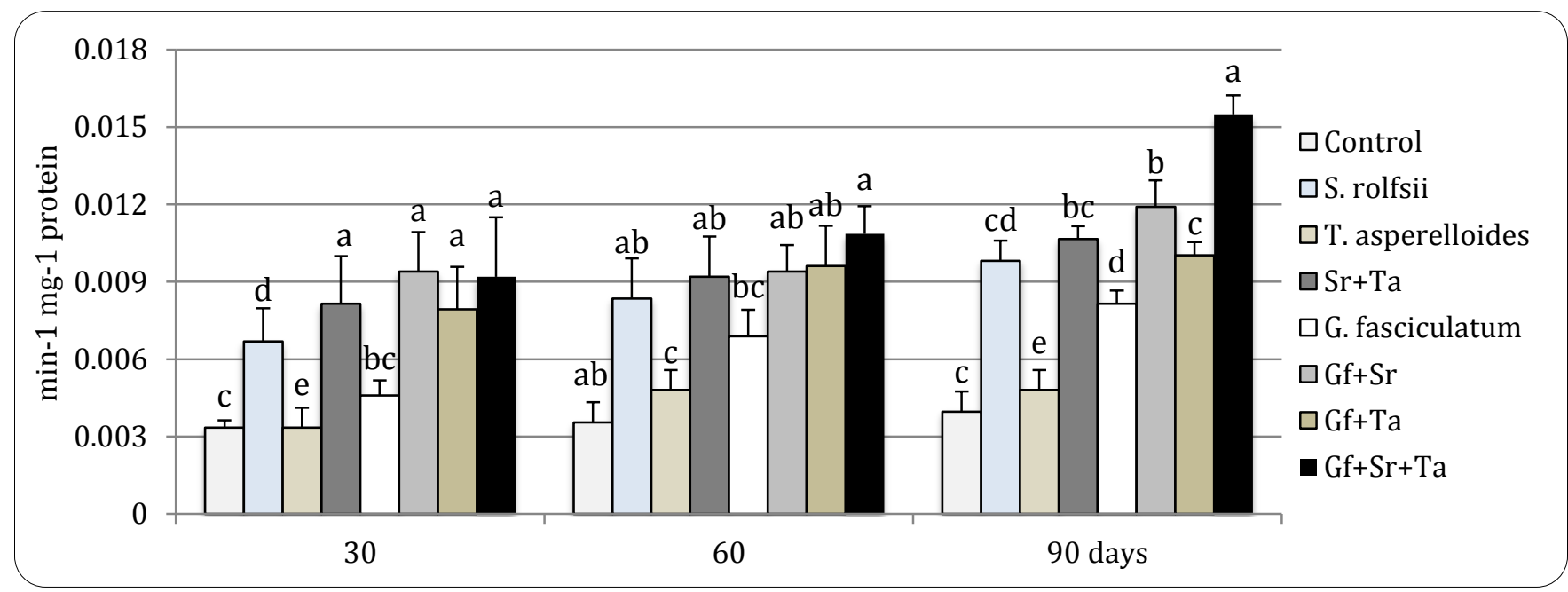

Figure 6. Peroxidase (PER) activity in roots of groundnut plants (W-51) inoculated with G. fasciculatum (Gf) and T. asperelloides (Ta) alone or in combinations infected with S. rolfsii $(\mathrm{Sr})$ and at different period of growth.

In the present investigation, the typical stem-rot symptoms appeared after 30 days of sowing only. The observation showed that there was decrease in severity of stem-rot due to treatment with AM fungi by $55.56 \%$ $(\mathrm{Gf}+\mathrm{Sr})$ or Trichoderma by $58.33 \%(\mathrm{Sr}+\mathrm{Ta})$ in groundnut plants as compared to diseased non-inoculated control ones by $66.67 \%(\mathrm{Sr})$ after 30 days of sowing. The lowest severity of disease was observed in groundnut plant where combined inoculations were made with AM fungi and Trichoderma by $41.67 \%(G f+S r+T a)$ after 90 days of sowing (Figure 7).

The colonization by AM fungus ( $G$. fasciculatum) observed in groundnut roots were determined by percentage of arbuscules which were significantly higher in only AM fungi healthy treatment by $62 \%(G f)$ followed by dual treatment of G. fasciculatum and T. asperelloides by $48 \%(G f+T a)$, than diseased $G$. fasciculatum treatment by $36 \%(G f+S r)$ and diseased G. fasciculatum and T. asperelloides treatment by $30 \%$ after 90 days of sowing ( $G f+S r+T a$ ) (Figure 8).

The content of chlorophyll was observed to be lowest in presence of pathogen where no inoculations of AM fungi or Trichoderma were made in groundnut plants after 30 , 60 and 90 days of sowing. But the content of total chlorophyll as illustrated in Figure 9, indicated highest increase in combined inoculation of $G$. fasciculatum and T. asperelloides in absence of pathogen $S$. rolfsii $(G f+T a)$ (13.940 mg chl./g) followed by single inoculation of AM fungi (Gf) (14.229 mg chl./g) and Trichoderma (Ta) (11.795 mg chl./g) after 60 days of sowing. The groundnut plants in presence of pathogen where 
combined inoculations of both $G$. fasciculatum and $T$. asperelloides were made showed maintenance of good chlorophyll content (18.455 $\mathrm{mg} \mathrm{chl} . / \mathrm{g}$ for $\mathrm{G} f+\mathrm{Sr}+\mathrm{Ta}$ ) as compared to single application of either $G$. fasciculatum $(G f+S r)(17.924 \mathrm{mg}$ chl./g) or T. asperelloides $(\mathrm{Sr}+\mathrm{Ta})$ (14.829 mg chl./g) after 90 days of sowing (Figure 9).

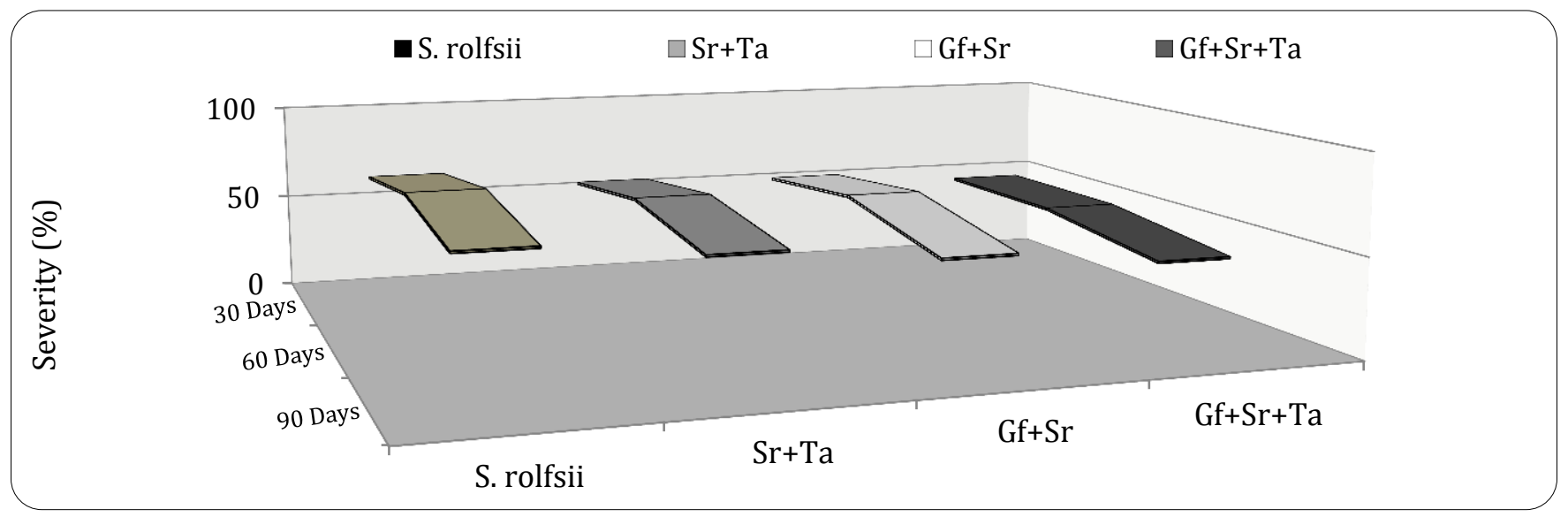

Figure 7. The percentage disease severity in groundnut plants (W-51) inoculated with G. fasciculatum (Gf) and T. asperelloides (Ta) alone or in combinations infected with S. rolfsii (Sr) and at different period of growth.

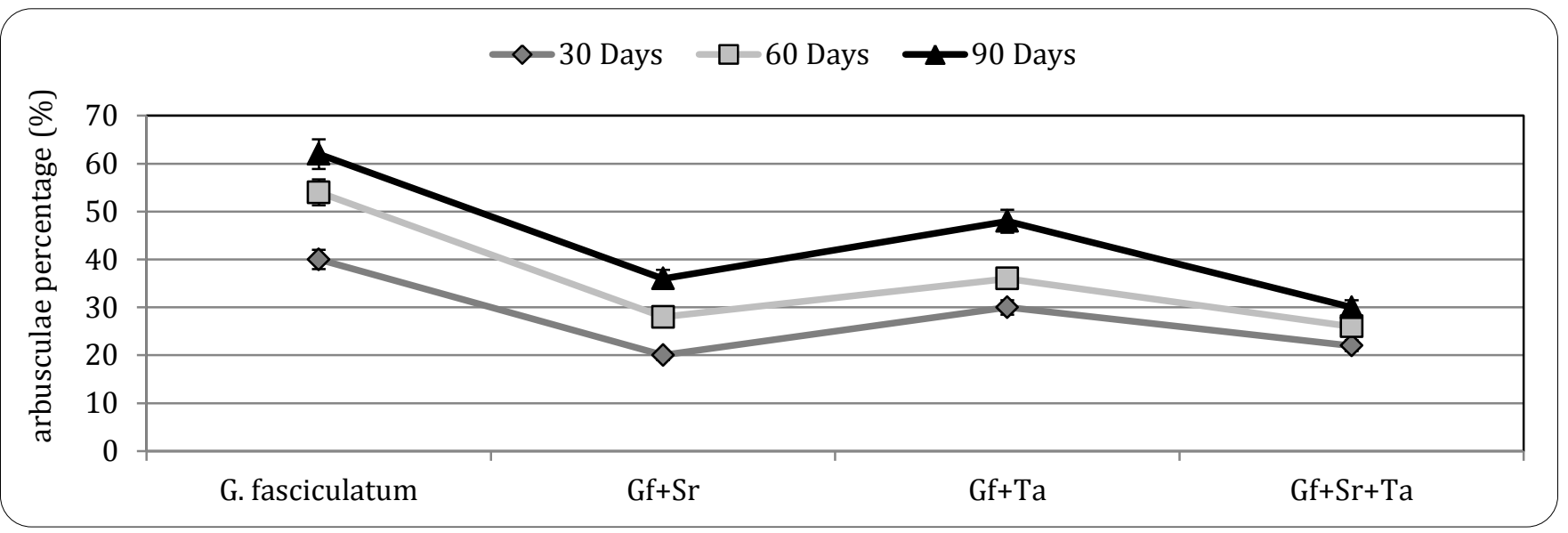

Figure 8. The percentage arbuscules in groundnut plants (W-51) inoculated with G. fasciculatum (Gf) and $T$. asperelloides (Ta) alone or in combinations infected with S. rolfsii (Sr) and at different period of growth.

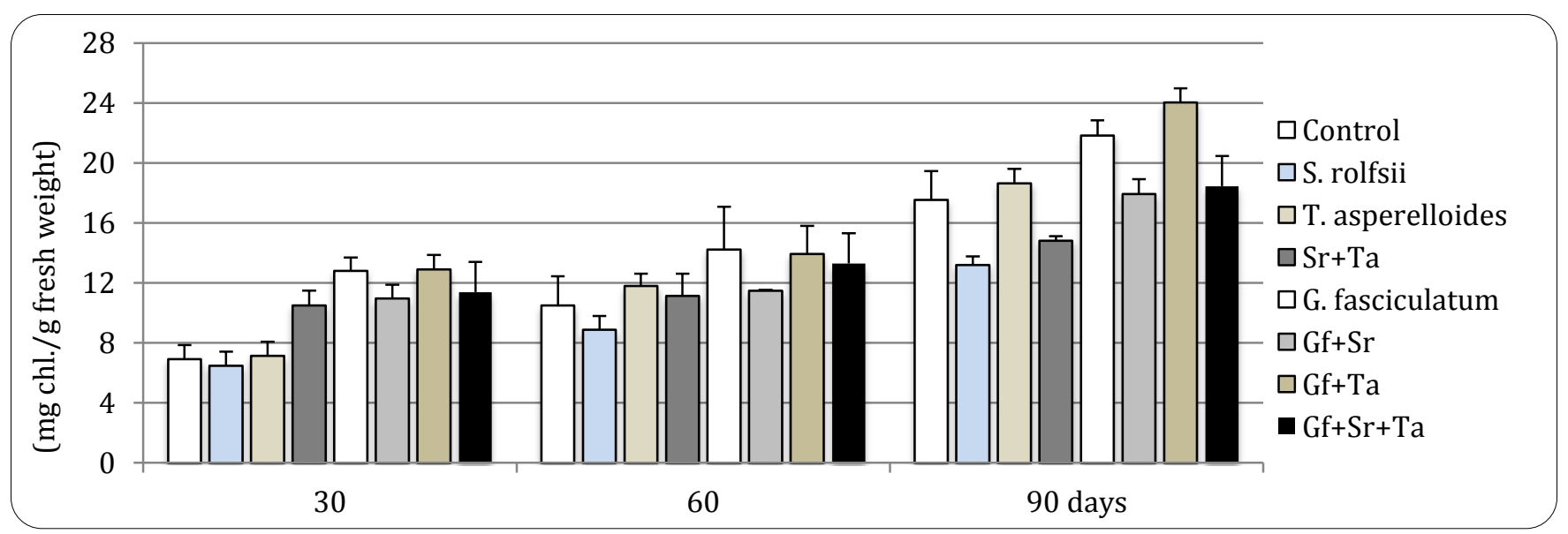

Figure 9. The chlorophyll content in groundnut plants (W-51) inoculated with G. fasciculatum (Gf) and T. asperelloides (Ta) alone or in combinations infected with S. rolfsii (Sr) and at different period of growth. 


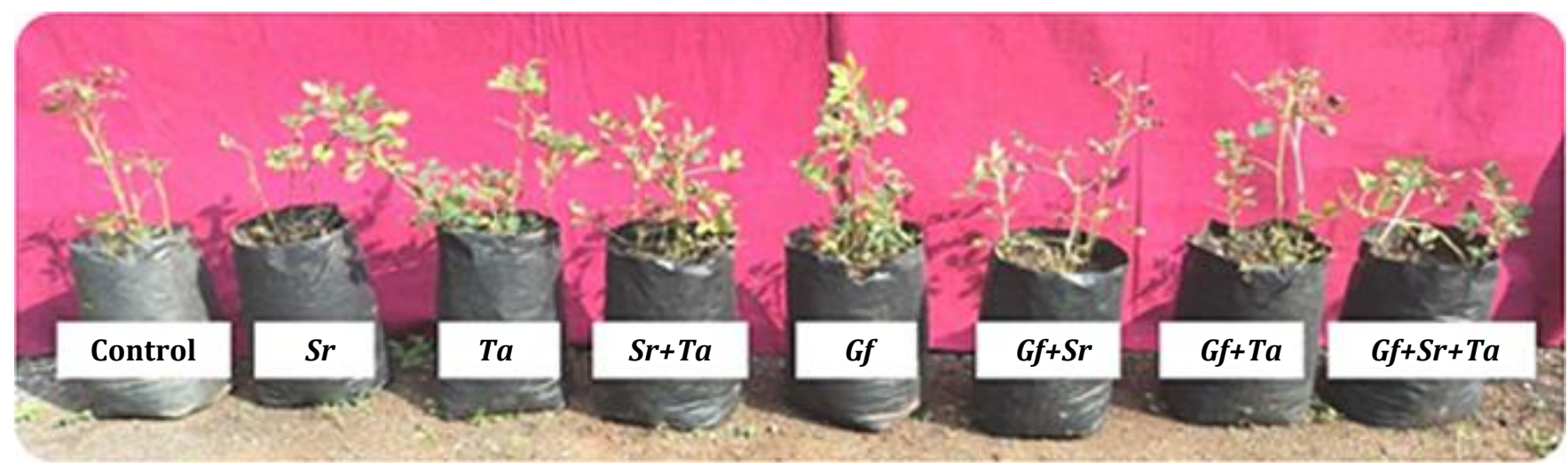

Figure 10. Growth responses of groundnut plants after 90 days of G. fasciculatum, T. asperelloides treatment and pathogen S. rolfsii inoculation.

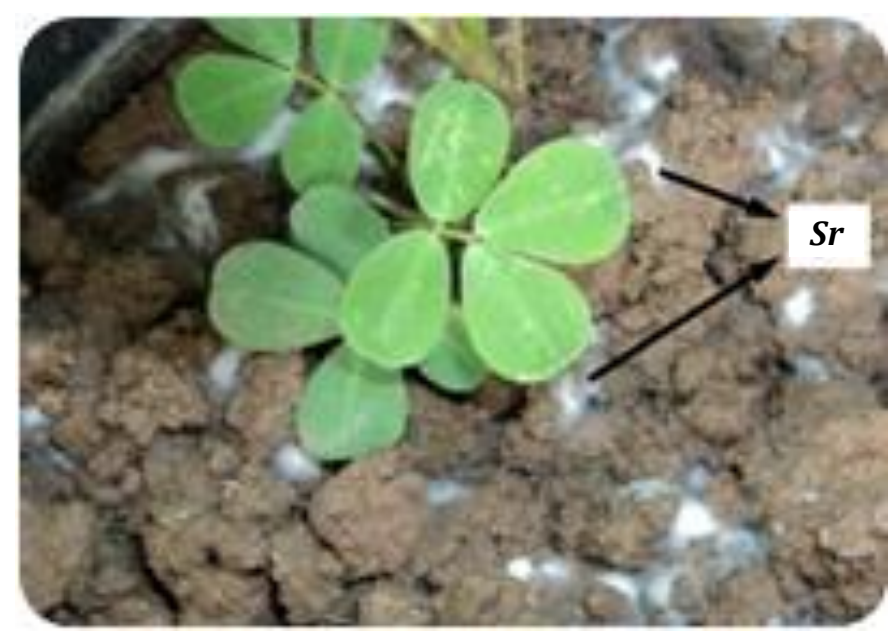

Figure 11. S. rolfsii $(S r)$ showing white mycelial growth in soil.

\section{DISCUSSION}

The application of antagonists ( $G$. fasciculatum and $T$. asperelloides) in various combinations with pathogen $S$. rolfsii (see Material and methods) resulted into variable physiological, biochemical and anti-oxidative enzyme activities in groundnut plant (cv. W-51). For instance, the variation in acid and alkaline phosphatase activities signifies the role played by $G$. fasciculatum and $T$. asperelloides in bringing of inorganic phosphates. As the phosphatase activity is required for the maintenance of cellular metabolism in plants (Tabaldi et al., 2007). Moreover, the increase in phosphatase activity due to AM association in rhizosphere has been studied as it gives rise to alterations in phosphorous supply (Allen, 1995). The hyphal networks of AM fungi are specialized structures which are responsible for the uptake of nutrient (phosphate) in host plants. That is why, in the present study phosphatase activities were observed to be higher due to AM inoculations. Moreover, the highest

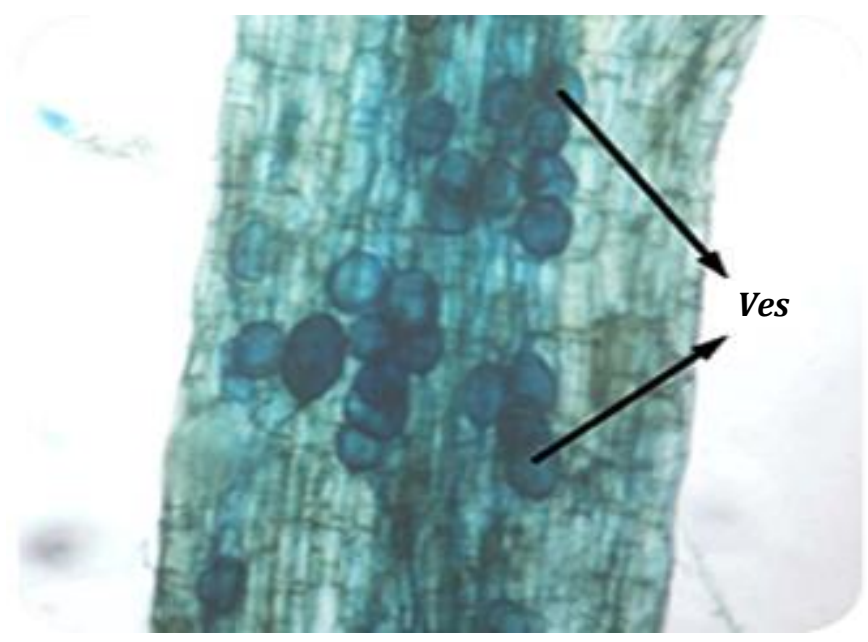

Figure 12. Vesicular colonization (Ves.) in the roots of groundnut plants after 90 days of AM inoculation (20X).

phosphatase activities was observed in the combined application of $G$. fasciculatum and T. asperelloides in presence of pathogen $(G f+S r+T a)$ after 90 days of sowing which may be correlated to lower severity of disease during that period. Also, there was lower percentage of arbuscules after 90 days of sowing which is considered to be the site of nutrient exchange (Parniske, 2008). So, the increased phosphatase activities in spite of lower arbuscules demonstrated possibility of direct involvement of phosphatase enzyme in the acquisition of phosphorous.

The cell wall of plant contains proteins that actively works during cell growth and strengthens the wall of host plants during defense resistance (Freeman and Beattie, 2008). Hence, the results obtained in the present study may be correlated to increased protein content during $S$. rolfsii attack and highest protein being observed in combined treatment of AM fungi along with Trichoderma $(G f+S r+T a)$ in groundnut plants as 
compared to any other treatments. The inhibition of fungal pathogens due to mycorrhiza (G. versiforme) colonization is associated with activation of pathogenesis-related proteins by Li et al. (2006) in Vitis amuren Rupr. against Meloidogyne incognita and Saksirirat et al. (2009) reported enhanced PR protein in tomato when treated with Trichoderma spp. isolates against Stemphylium solani.

The accumulation of PPO plays an important role in plants defense mechanism for inhibition of pathogens by the mechanism of cell wall reinforcements (Ngadze et al., 2012). That is why, from the present investigation it was noted that $S$. rolfsii inoculation $(S r)$ led to significant increase in PPO activity as compared to T. asperelloides $(\mathrm{Ta}$ ) or G. fasciculatum (Gf) inoculations. The PPO activity increased even more in diseased groundnut when inoculated along with $G$. fasciculatum $(G f+S r)$ or $T$. asperelloides $(\mathrm{Sr}+\mathrm{Ta})$ but highest PPO activity was observed in dual inoculation of both $G$. fasciculatum and T. asperelloides $(\mathrm{G} f+\mathrm{Sr}+\mathrm{Ta})$ in presence of pathogen. In a similar way, Mathur and Vyas (1996) and Jayalakshmi et al. (2009) reported higher polyphenol oxidase in mycorrhizal and Trichoderma treated plants respectively.

In plant, one of the earliest responses to the pathogen attack is accumulation of phenolics for lignin synthesis or peroxidase enzyme activity which also possesses fungitoxic activity (Sasaki et al., 2004). Hence, the present study demonstrated that total phenol and PER activity was increased due to pathogen inoculation with or without G. fasciculatum and T. asperelloides but was significantly highest when both $G$. fasciculatum and $T$. asperelloides were inoculated in presence of $S$. rolfsii. The AM fungi or Trichoderma-specific peroxidase activities in the present investigation indicates their increased expression during their associations in host groundnut plants against pathogen $S$. rolfsii infection when compared with control ones. This concept may be correlated to the works of Blilou et al. (2000) who showed increase in peroxidase activity in mycorrhizal tobacco plants and Christopher et al. (2010) showed significantly higher level of peroxidase activities were induced in tomato by $T$. virens against Fusarium oxysporum $\mathrm{f} s \mathrm{~s}$. lycopersici than control ones.

The significant decrease in severity of disease in groundnut cultivar (W-51) was observed in the present study by application of $G$. fasciculatum and $T$. asperelloides. The decrease in severity of disease was brought about considerably AM application $(G f+S r)$ as compared to Trichoderma application $(\mathrm{Sr}+\mathrm{Ta})$ but combination of $G$. fasciculatum and $T$. asperelloides in presence of $S$. rolfsii $(G f+S r+T a)$ was found to be most effective when compared to any other treatments. Similarly, Sennoi et al. (2013) demonstrated lowest disease incidence $(30 \%)$ caused by $S$. rolfsii in Helianthus tuberosus L. in combined inoculation of AM fungi (G. clarum) and T. harzianum. In the present investigation, the $G$. fasciculatum may have played significant role in pathogen (S. rolfsii) resistance by the mechanism of improved nutrition (Smith and Read, 2008) or root damage compensation (Whipps, 2004). The decrease in severity of disease brought upon by $T$. asperelloides may be due to their mechanism of mycoparasitic activity (Druzhinina et al., 2011).

In general during development of AM colonization, a tree-shaped structures known as arbuscules (bush or little tree) are formed which are thought to be the site of nutrient exchange between the AM fungi and host plant (Parniske, 2008). In the present study, the colonization by AM fungi in terms of percentage of arbuscules was noted which showed variation in their percentage with G. fasciculatum or $T$. asperelloides or $S$. rolfsii inoculations. Here, in only G. fasciculatum (Gf) treatment showed highest percentage of arbuscules probably due to hardly any competition for space and nutrients offered by either $T$. asperelloides or pathogen $S$. rolfsii followed by $G f+T a, G f+S r$ and $G f+S r+T a$ treatments where T. asperelloides and $S$. rolfsii may have influenced the percentage of arbuscules. In a similar study the frequency of arbuscules has been reported to be reduced in Phaseolus vulgaris L. due to the presence of pathogen Fusarium solani (Al-Aksar and Rashad, 2010).

The absorption of light is in plants is carried out by antenna complexes comprising chlorophylls which can dispose photon energy required by the plants (Taiz and Zeiger, 2002). Thus, the chlorophyll which is a major chloroplast component plays significant role during photosynthesis and in overall good condition of plant health. In the present study, the increased content of chlorophyll demonstrated the importance of $G$. fasciculatum or T. asperelloides inoculations alone or in combinations. Also, in the presence of pathogen S. rolfsii, combined inoculation of $G$. fasciculatum along with $T$. asperelloides were found to be most effective in groundnut plants as compared to their single inoculations. Moreover, the beneficial associations of AM 
fungi and Trichoderma species may be correlated here which are known to improve photosynthetic efficiency in host plants (Sheng, 2008; Harman et al. 2012). Likewise, the study by Tanwar et al. (2013) demonstrated that the chlorophyll content got increased significantly in combined inoculation of AM fungi and T. viride than their single inoculation in broccoli.

\section{CONCLUSION}

In conclusion, the beneficial application of microbial inoculants ( $G$. fasciculatum and T. asperelloides) in the present investigation demonstrated the possible opportunities in decreasing the harmful attributes of soil-borne pathogens in a biological way and also, showed the potential economical alternative for costly chemical fertilizers. The decreased severity of disease due to single application of AM fungi or Trichoderma before plantation of groundnut plants suggests their capacity to inhibit soil-borne plant pathogens but their combined inoculations resulted into better inhibition. Furthermore, the up-regulations of various physiological, bio-chemical and anti-oxidant enzyme activities by AM fungi and Trichoderma treatments suggest its ability to biologically protect the groundnut plants from soil-borne plant pathogen. Thus, it opens up low input agriculture system with environmental friendly application aspects.

\section{ACKNOWLEDGMENT}

Author is thankful to University of Pune, India and University Grants Commission, New Delhi, India for providing necessary facilities and scholarship.

\section{References}

Al-Aksar, A.A. and Y.M. Rashad. 2010. Arbuscular Mycorrhizal Fungi: A Biocontrol Agent against Common Bean Fusarium Root Rot Disease. Plant Pathol. 9: 31-38.

Allen, E.B., M.F. Allen, D.J. Helm, J.M. Trappe, R. Moliva and E. Rincon. 1995. Patterns and regulation of mycorrhizal and fungal diversity. Plant and Soil. 170: 47-62.

Arnon, D.J. 1949. Copper enzymes in isolated chloroplasts. J Plant Cell Physiol. 4: 29-30.

Blilou, I., P. Bueno, J.A. Ocampo, J.M. Garcia-Garrido. 2000. Induction of catalase and ascorbate peroxidase activities in tobacco roots inoculated with the arbuscular mycorrhizal fungus Glomus mosseae. Mycol Res. 104: 722-725.

Christopher, D.J., T.S. Raj, S.U. Rani and R. Udaykumar. 2010. Role of defense enzymes activity in tomato as induced by Trichoderma virens against Fusarium wilt caused by Fusarium oxysporum f sp. lycopersici. J Biopesticides. 3: 158-162.

Druzhinina, I.S., V. Seidl-Seiboth, A. Herrera-Estrella, B.A. Horwitz, C.M. Kenerley, E. Monte, P.K. Mukherjee, S. Zeilinger, I.V. Grigoriev, C.P. Kubicek. 2011. Trichoderma: the genomics of opportunistic success. Nat Rev Microbiol. 9: 749-759.

Freeman, B.C. and G.A. Beattie. 2008. An Overview of Plant Defenses against Pathogens and Herbivores. The Plant Health Instructor. DOI: 10.1094/PHI-I2008-0226-01.

Gerdemann, J.W. and T.H. Nicholson. 1963. Spores of Mycorrhizal Endogene species extracted by wet sieving and decanting. Trans Brit Mycol Soc. 46: 235-244.

Harman, G.E., A.H. Herrera-Estrella, B.A. Horwitz and M. Lorito. 2012. Trichoderma - from basic biology to biotechnology. Microbiol. 158: 1-2.

Hermosa, R., A Viterbo, I.I. Chet and E. Monte. 2010. Plant-beneficial effects of Trichoderma and of its genes. Microbiol. 158: 17-25. DOI: 10.1099/mic.0.052274-0.

Jaklitsch, W.M., G.J. Samuels, A. Ismaiel and H. Voglmayr. 2013. Disentangling the Trichoderma viridescens complex. Persoonia. 31: 112-146.

Jayalakshmi, S.K., S. Raju, S.U. Rani, V.I. Benagi and K. Sreeramulu. 2009. Trichoderma harzianum $\mathrm{L}_{1}$ as a potential source for lytic enzymes and elicitor of defense responses in chickpea (Cicer arietinum L.) against wilt disease caused by Fusarium oxysporum f. sp. ciceri. Aus J Crop Sci. 3: 44-52.

Kokalis-Burelle, N., D.M. Porter, R. Rodriguez-Kabana, D.H. Smith and P. Subrahmanyamm. 1997. Compendium of Peanut Diseases, 2nd ed. APS Press, St. Paul.

Li, H.Y., G.D. Yang and H.R. Shu. 2006. Colonization by the arbuscular mycorrhizal fungus Glomus versiforme induces a defense response against the root-knot nematode Meloidogyne incognita in the grapevine (Vitis amurensis Rupr.), which includes transcriptional activation of the class III chitinase gene. VCH3. Plant Cell Physiol, 47: 154-163.

Lowry, O.H., N.J. Rosenbrough, A.L. Far and R.J. Randall. 1951. Protein measurement with the Folin-Phenol reagent. J Biol Chem. 193: 265-275.

Lowry, O.H., N.R. Roberts, W.S. Mei-Ling and Crawford. 1954. The quantitative histochemistry of brain II. 
Enzyme measurement. J Biol Chem. 207: 19-37.

Madan Mohan, M. and S.N. Nigam. 2013. Principles and Practices for Groundnut Seed Production in India. Information Bulletin No. 94. Patancheru 502 324, Andhra Pradesh, India: International Crops Research Institute for the Semi-Arid Tropics. Pp. 64.

Mahadevan, A. and R. Shridhar. 1982. Methods in physiological plant pathology. Second edition, Sivakami publication, Madras. Pp. 153-155.

Malick, C.P. and M.B. Singh. 1980. Phenolics. In: Plant enzymology and histo enzymology, Kalyani publishers, New Delhi. Pp. 286.

Mathur, N. and A. Vyas. 1996. Biochemical changes in Ziziphus xyloropus by VA mycorrhizae. Botanical Bull. Academia Sinica. 37: 209-212.

Mehan, V.K., C.D. Mayee and D. McDonald. 1994. Management of Sclerotium rolfsii caused stem and pod rots of groundnut a critical review. International J Pest Management. 40: 313-320.

Melouk, H.A. and P.A. Backman. 1995. Management of Soilborne Fungal Pathogens. In: Melouk, H.A. and Shokes, F.M. (Ed.) 1995: Peanut health management. APS Press, St. Paul, MN. 75-85.

Mukherjee, P.K., A.K. Mukherjee and S. Kranthi. 2013. Reclassification of Trichoderma viride (TNAU), the most widely used commercial biofungicide in India, as Trichoderma asperelloides. Open Biotechnological J. 7: 7-9. DOI:10.2174/1874070701307010007

Ngadze, E., D. Icishahayo, T.A. Coutinho and J.E. van der Waals. 2012. Role of polyphenol oxidase, peroxidase, phenylalanine ammonia lyase, chlorogenic acid, and total soluble phenols in resistance of potatoes to soft rot. Plant Dis. 96: 186-192.

Parniske, M. 2008. Arbuscular mycorrhiza: the mother of plant root endosymbioses. Nat Rev Microbiol. 6: 763-775.

Putter, J. 1974. Peroxidase. In: Bergmeyer, H.U. (Ed.) 1974: Methods of enzymatic analysis. Academic Press, New York, USA. Pp. 567-1124.

Reithner, B., E. Ibarra-Laclette, R.L. Mach, A. HerreraEstrella. 2011. Identification of mycoparasitismrelated genes in Trichoderma atroviride. Appl Environ Microbiol. 77: 4361-4370.

Saksirirat, W., P. Chareerak and W. Bunyatrachata. 2009. Induced systemic resistance of biocontrol fungus, Trichoderma spp. against bacterial and gray leaf spot in tomatoes. As J Food Ag-Ind. Special Issue. S99-S104.

Sasaki, K., T. Iwai, S. Hiraga, K. Kuroda, S. Seo, I. Mitsuhara, A. Miyasaka, M. Iwano, H. Ito, H. Matsui and Y. Ohashi. 2004. Ten rice peroxidases redundantly respond to multiple stresses including infection with rice blast fungus. Plant Cell Physiol. 45: 1442-1452.

Sennoi, R., N. Singkham, S. Jogloy, S. Boonlue, W. Salsirirat, T. Kesmala and A. Patanothai. 2013. Biological control of southern stem rot caused by Sclerotium rolfsii using Trichoderma harzianum and arbuscular mycorrhizal fungi on Jerusalem artichoke (Helianthus tuberosus L.). Crop Prot. 54: 148-153.

Sheng, M., M. Tang, H. Chen, B. Yang, F. Zhang and Y. Huang. 2008. Influence of arbuscular mycorrhizae on photosynthesis and water status of maize plants under salt stress. Mycorrhiza. 18: 287-96.

Shokes, F.M., K. Rhogalski, D.W. Gorbet, T.B. Brenneman and D.A. Berger. 1996. Techniques for inoculation of peanut with Sclerotium rolfsii in the greenhouse and field. Peanut Sci. 23: 124-128.

Singh, G. and K.G. Mukherji. 2006. Root exudates as determinant of rhizospheric microbial diversity. In: Mukerji, K.G., Manoharachary, C. and Singh, J. (Ed.) 2006: Microbial activity in the rhizosphere. Springer Verlag, Berlin, Heidelberg. Pp. 39-55.

Smith, S.E. and R.J. Read. 2008. Mycorrhizal symbiosis. $3^{\text {rd }}$ edition. Academic Press, London, UK.

Tabaldi, L.A., R. Ruppenthal, D. Cargnelutti, V.M. Morsch, L.B. Pereira and M.R.C. Schetinger. 2007. Effects of metal elements on acid phosphatase activity in cucumber (Cucumis sativus L.) seedlings. Environ Exp Bot. 59: 43-48.

Taiz, L. and E. Zeiger. 2002, Plant physiology, third ed. Sinauer, Sunderland. Pp. 690.

Tanwar A., A. Aggarwal, S. Kaushish and S. Chauhan. 2013. Interactive effect of AM fungi with Trichoderma viride and Pseudomonas fluorescens on growth and yield of broccoli. Plant Protect Sci. 49: 137-145.

Topolovec-Pintaric, S., S. Zutic and E. Dermic. 2013.

Enhanced growth of cabbage and red beet by Trichoderma viride. Acta agriculturae Slovenica. 101: 87-92.

Trappe, J.M. 1982. Synoptic key to the genera and species of Zygomycetous mycorrhizal fungi. Phytopathol. 72: 1102-1108. 
Trouvelot, A., J.L. Kough and V. Gianinazi-Pearson. 1986. Mesure du Taux de Mycorhization V A d'un Systeme Radiculaire Recherche de Methods D'estimation Ayant Une Signification Fonctionnelle. In: Gianinazzi-Pearson, V. and Gianinazzi, S. (Eds.) 1986: Physiological and Genetical Aspects of Mycorrhizae, INRA Publications, Paris. Pp. 217-221.
Whipps, J.M. 2004. Prospects and limitations for mycorrhizas in biocontrol of root pathogens. Can J Bot. 82: 1198-1227.

Ziedan, E.H., I.S. Elewa, M.H. Mostafa and A.F. Sahab. 2011. Applications of mycorrhizae for controlling root rot diseases of sesame. J Plant Protect Res. 51: 354-361. 